\title{
Social Movements and Civil Society in Taiwan
}

\section{A Typological Analysis of Social Movements and Public Acceptance}

HSIN-HUANG MICHAEL HSIAO

\section{Introduction}

Since the 1980s, there have been three waves of emergent social movements that have taken place in Taiwan's civil society. The first wave of organized social movements took place between 1980 and 1986 before the lifting of martial law in July 1987 which signified political liberalization. ${ }^{1}$ There were seven movements in this first wave:

1) the consumers' movement (1980 -)

2) the anti-pollution protest movement (1980 -)

3) the nature conservation movement (1982 -)

4) the women's movement (1982 -)

5) the aborigines' movement (1983 -)

6) the students' movement (1986 -)

7) the New Testament church protests (1986 -)

The second wave of organized civil protests and social movements was initiated in 1987, the year that the ruling KMT (Kuomintang) party-state finally took steps toward liberalization and democratization by lifting martial law, permitting the formation of new political parties, and allowing the establishment of new organs of the press. In that single year, a further seven social movements emerged:

8) the labour movement (1987-)

9) the farmers' movement (1987-)

10) the teachers' movement (1987-)

11) the handicapped and disadvantaged welfare group protests (1987-)

12) the veterans' movement (1987-92)

13) the political prisoners' human rights movement (1987-90) 
14) the Mainlanders' home-visiting movement (1987-90)

The third, most recent wave took place after the lifting of martial law. Further steps were taken at this time for a major restructuring of the political system. A total of five social movements were observed during this post-authoritarian period of political transformation:

15) the Taiwanese home-returning movement (1988-93)

16) the Hakka movement (1988 -)

17) the anti-nuclear power movement (1988 -)

18) the non-homeowners' "shell-less snail" movement (1989 -)

19) the judiciary reform movement (1990 -)

The past fourteen years of Taiwan's post-war era have witnessed the rise of a vociferous civil society, as manifested by the abovementioned nineteen social movements. ${ }^{2}$ It is evident that the majority of the social movements organized by different sectors or groups were initiated either before or at the time of political liberalization. There also exists a dialectic relationship between the social movements and political democratization. The pressures emanating from the first- and second-wave social movements have led to the realization of political transformation. Reciprocally, once political control loosened, this accelerated the further mobilization and formation of a third wave of social movements. In other words, the KMT's democratizing stance did not happen spontaneously: it was a concession to the increasing demands from the mobilized civil society.

Though political opposition had long existed under authoritarian rule, it alone could not account for the accelerating intensive pressure of organized social movements. It is equally important to point out that only five social movements were organized in the six years of the post-martial law era (as of December 1993). This may reflect the saturation of demands, issues and resources that could be mobilized by the civil society. ${ }^{3}$

Among the nineteen social movements, although each has had specific objectives, all have demanded a change in the state-society relations under authoritarianism. Most social movements demanded more autonomy free from the state's tight control, as in the cases of the labour movement, students' movement, and judiciary movement. Others requested more active and proper policy intervention from the state, as in the cases of the consumers' movement, the 
environmental movement, the welfare movement, the "shell-less snail" movement, and the farmers' movement.

By the end of 1993, fourteen social movement were still in existence, while the other five social movements (i.e. the New Testament church protests; the veterans' movement; the political victims' movement; the Mainlanders' home-visiting movement; and the Taiwanese home-returning movement) had already ceased to operate either because their immediate objectives had been accomplished or because their causes had been absorbed by the state's responding policies or actions.

Looking into the demise of these five social movements, it is evident that they all shared the following characteristics:

- Their key participants and organizers were clearly defined.

- Their capacity to mobilize internal resources was high.

- Their causes and objectives were specific.

- Their immediate pressures or threats were easily felt by the state.

It could be these factors that the state responded to when it increased the monthly allowance and compensation for the veterans and redeemed the land certificates that had been allocated in the 1950s. The state also showed its responsiveness when it permitted the ethnic Mainlanders to visit their hometowns and relatives on the Mainland, thereby relaxing control on the return of overseas dissident Taiwanese. Finally, the state granted civil rights to former political prisoners, and agreed that the New Testament church members could settle in a previously prohibited mountain area.

The nineteen social movements that have arisen since the 1980s in Taiwan can be classified into four respective types in terms of (a) their ability to mobilize internal resources and (b) the degree of immediate pressure or threat they were able to exert on the state's policies (see table 1).

- Type 1 social movements had high level of internal mobilization and exerted a high degree of pressure so that the state had to move fast to respond to their demands. The above-mentioned five social movements that have ceased to operate all belonged to this type.

- Type 2 social movements include: the consumers' movement, the environment movement (anti-pollution, conservation and antinuclear power movements), the students' movement, the teachers' right movement, and the Hakka movement. All these, though 
they have high level of internal mobilization capability, exert a low immediate threat on the state.

- Type 3 social movements of which the labour movement and the farmers' movement are typical examples, could exert maximum pressure on the state, but their ability to mobilize internal resources is rather low.

- Type 4 social movements include the aborigines' movement, the handicapped welfare movement, the women's movement, the judiciary reform movement and the non-homeowners' movement. All have low level of capability of resource mobilization and a low immediate threat level for the state.

In retrospect, the KMT state in Taiwan in the 1980s responded effectively to the Type 1 and the Type 3 social movements by changing the existing related policies or laws. But the state's reaction to the Type 2 and the Type 4 social movements has been rather reluctant and slow.

Table 1: Typology of social movements in Taiwan since the 1980s

\begin{tabular}{|c|c|c|}
\hline \multirow{2}{*}{$\begin{array}{l}\text { Degree } \\
\text { of } \\
\text { immediate } \\
\text { pressure on } \\
\text { the state }\end{array}$} & \multicolumn{2}{|c|}{$\begin{array}{l}\text { Level of capacity to mobilize } \\
\text { internal resources }\end{array}$} \\
\hline & High & Low \\
\hline High & $\begin{array}{l}\text { Type } 1 \\
\text { Veterans' movement (1987-1992) } \\
\text { Mainlanders' home-visiting movement } \\
\quad(1987-1990) \\
\text { Taiwanese home-returning movement } \\
\quad(1987-1993) \\
\text { Political prisoners' human rights } \\
\text { movement (1987-1990) } \\
\text { New Testament Church protest } \\
\text { (1986-1989) }\end{array}$ & $\begin{array}{l}\text { Type } 3 \\
\text { Labour movement (1987-) } \\
\text { Farmers' movement (1987-) }\end{array}$ \\
\hline Low & $\begin{array}{l}\text { Type } 2 \\
\text { Consumers' movement (1980-) } \\
\text { Environmental movement (1980-) } \\
\text { Students' movement (1986-) } \\
\text { Teachers' right movement (1987-) } \\
\text { Hakka movement (1988-) }\end{array}$ & $\begin{array}{l}\text { Type } 4 \\
\text { Women's movement (1982-) } \\
\text { Aborigines' movement (1983-) } \\
\text { Handicapped welfare movement } \\
\quad(1987-) \\
\text { Non-homeowners' movement } \\
\quad(1989-) \\
\text { Judiciary reform movement } \\
(1990-)\end{array}$ \\
\hline
\end{tabular}

Such a typology is useful in identifying the differing characteristics of the social movements and in predicting the probable reaction of the state to individual ones. In other words, the patterns of interaction between the mobilized civil society and the state under 
pressure can be more or less delineated in the typology. Moreover, the effectiveness of social movements in achieving their stated objectives can also be determined. In this effort to classify the nineteen social movements, the assumption is that the social movements can be treated as an emerging social reality. In Taiwan since the 1980s, these nineteen social movements have clearly emerged as a new social force in the transformation of state-society relations.

\section{Research Background}

This essay provides another perspective from which to analyze and classify the social movements in Taiwan: that is, from the public's acceptance of the social movement phenomenon. Public acceptance here means both the public's perception of different social movements and the level of support it accords them. By analyzing public perception and support, a different typology of social movements will emerge. A comparison between the above objective classification and this subjective typology will be made. It is suggested that by applying these two classification schemata, one can reach a better understanding of the dynamics behind the Taiwanese social movements in the 1990s.

The data to be analyzed in this essay are drawn from two consecutive island-wide surveys in February 1991 and August 1992 of the ongoing General Social Attitude Surveys conducted by the Sun Yat-Sen Institute for Social Sciences and Philosophy, Academia Sinica, and supported by ROC's National Science Council. Both surveys were conducted by trained interviewers and the sample was selected in three stages from 328 townships that were stratified according to administrative level, degree of urbanization and socio-economic development indicators. A total of 1,605 and 1,523 adult respondents were interviewed in 1991 and 1992 respectively.

The questions on social movements in both surveys were designed by this author and then discussed and approved by a panel of sociologists participating in the project. In the 1991 survey, twelve social movements were included in the sample, while in 1992 eleven social movements were listed in order to examine the respondents' self-reported understanding and support of each of the listed social movements. Not all of the nineteen movements mentioned above were included because some had already ceased to be active, such as 
the five movements of Type 1. Furthermore, some were not commonly known to the general public (such as the teachers' right movement and the Hakka movement) and some shared a common theme and could be classified as one general movement (such as the environment-related anti-pollution, conservation and anti-nuclear power movements). The following ten social movements, were chosen for the two surveys:

1) the consumers' movement

2) the environmental movement

3) the aborigines' movement

4) the students' movement

5) the labour movement

6) the farmers' movement

7) the handicapped welfare movement

8) the women's movement

9) the judiciary reform movement

10) the non-homeowners' movement

These ten social movements are included in Types 2 to 4 of table 1 .

To measure the positive level of understanding, the reply options "understand very well" and "understand to some degree" were used in both 1991 and 1992 surveys. If 50 per cent or more of the respondents answered that they "understand very well" or "understand to some degree" a specific social movement, it was regarded as a high public understanding level. But for the negative level of understanding, "never heard of", "only heard about" and "do not understand well" were listed in 1991, while in 1992 "do not understand well" and "understand only a little" were used. Also, in the 1992 survey, the respondents were asked first if they had ever heard of each of the social movements. Therefore, only the positive answers have been used for the actual analysis.

To measure the degree of support for the movements, the following three reply options were used in both surveys: "support", "no opinion" and "do not support". However, for actual analysis, only the "support" answers were used. 


\section{The Public's Unfamiliarity, Understanding and Support vis-à-vis Social Movements: 1991-92}

\section{Unfamiliarity with Social Movements}

Before analyzing the public's understanding of the ten social movements, it is helpful to examine the level of unfamiliarity with this emerging social phenomenon among the general public. The indicator is measured by the answer of "never heard of" from the respondents (see table 2).

Table 2: Public understanding and support of social movements, 1991-92

\begin{tabular}{|l|c|c|c|c|c|c|}
\hline & \multicolumn{3}{|c|}{1991} & \multicolumn{3}{c|}{1992} \\
\hline $\begin{array}{c}\text { Understanding } \\
(\%)\end{array}$ & $\begin{array}{c}\text { Support } \\
(\%)\end{array}$ & $\begin{array}{c}\text { Never heard } \\
\text { of (\%) }\end{array}$ & $\begin{array}{c}\text { Understanding } \\
(\%)\end{array}$ & $\begin{array}{c}\text { Support } \\
(\%)\end{array}$ & $\begin{array}{c}\text { Never heard } \\
\text { of (\%) }\end{array}$ \\
\hline $\begin{array}{l}\text { Consumers' } \\
\text { movement }\end{array}$ & 51.8 & 73.8 & 18.5 & 57.4 & 78.5 & 41.8 \\
\hline $\begin{array}{l}\text { Environmen- } \\
\text { tal movement }\end{array}$ & 68.3 & 82.4 & 21.8 & 79.5 & 87.7 & 17.5 \\
\hline $\begin{array}{l}\text { Aborigines' } \\
\text { movement }\end{array}$ & 36.9 & 35.2 & 44.9 & 47.8 & 41.0 & 50.3 \\
\hline $\begin{array}{l}\text { Students' } \\
\text { movement }\end{array}$ & 45.4 & 26.8 & 29.2 & 56.9 & 27.4 & 31.8 \\
\hline $\begin{array}{l}\text { Labour } \\
\text { movement }\end{array}$ & 52.2 & 46.1 & 24.2 & 66.2 & 48.2 & 23.6 \\
\hline $\begin{array}{l}\text { Farmers' } \\
\text { movement }\end{array}$ & 40.1 & 29.5 & 30.0 & 59.1 & 54.4 & 34.1 \\
\hline $\begin{array}{l}\text { Handicapped } \\
\text { movement }\end{array}$ & 34.8 & 66.2 & 32.1 & 59.4 & 71.9 & 37.1 \\
\hline $\begin{array}{l}\text { Women's } \\
\text { movement }\end{array}$ & 45.7 & 51.9 & 34.0 & 64.6 & 65.4 & 37.0 \\
\hline $\begin{array}{l}\text { Judiciary } \\
\text { reform } \\
\text { movement }\end{array}$ & 42.9 & 55.7 & 40.0 & 53.2 & 65.6 & 53.1 \\
\hline $\begin{array}{l}\text { Non- } \\
\text { homeowners' } \\
\text { movement }\end{array}$ & 61.3 & 58.4 & 26.7 & 76.8 & 71.6 & 22.7 \\
\hline
\end{tabular}

Notes: Understanding is measured by the positive responses from only those who are familiar with specific social movement. Support is measured by the positive responses from only those who are familiar with specific social movement.

First, the most noticeable change can be found in the increased per centage of people answering "never heard of" in relation to seven social movements between the 1991 and 1992 surveys. The greatest increase of public unfamiliarity is vis-ă-vis the consumers' move- 
ment, followed by the judiciary reform movement. The remaining five social movements that were also relatively unfamiliar to the respondents were the aborigines' movement, the handicapped welfare movement, the farmers' movement, the women's movement and students' movement. On the other hand, the environmental movement, the non-homeowners' movement, and the labour movement were the only three social movements, which registered as being more familiar, yet the change is insignificant.

Second, by using the "never heard of" response as the superficial measure of the publics' unfamiliarity, it is evident that between 1991 and 1992, the overall public unfamiliarity with most of the listed social movements increased. Such change can best be interpreted as a reflection of the slowing down or inactivism of those social movements and consequently the decreased coverage of them in the mass media. It is important to point out that between June 1990 and May 1992 under the premiership of General Hau Pei-tsun, the KMT state began to adopt a tougher stance towards the demands of the labour and environmental movements' both of which were perceived to be threatening business interests and the state's growth strategy. The criminal code was applied to suppress organized social protests.

Moreover, the economic recession confronting Taiwan since 1990 also created a new conservatism in Taiwan, which in turn often scapegoated social movements. Within the social movements, the available resources required for organizing and strengthening their activities gradually dried up and a new source had to be found. Against the background of these unfavorable external and internal conditions, social movements as a whole experienced a temporary yet obvious set-back in the first few years of 1990s.

Finally, it is quite clear that among the ten social movements (for both survey years), the public were most unfamiliar with the judiciary reform movement and the aborigines' movement. The social movements that benefited from the greatest familiarity in the eyes of public (for both years) were the environmental movement and then the labour movement and non-homeowners' movement. Less than one-quarter of the respondents in both years revealed their unfamiliarity with these three movements (see table 2). 


\section{Changes in the Public Understanding of Social Movements} From table 3, the following observations can be made: First, there has been an overall increase between 1991 and 1992 in the understanding score. In 1992, all social movements received an understanding score of over 50 per cent, except for the aborigines' movement. Moreover, in both 1991 and 1992, more than 50 per cent of the public reported a better understanding of the non-homeowners', labour, environmental and consumers' movements. In other words, these four social movements can be regarded as the movements best understood by the general public in Taiwan society in the early 1990s.

Table 3: Rank order of changes in public understanding of social movements, 1991-92.

\begin{tabular}{|l|c|c|c|}
\hline \multicolumn{4}{|c|}{ Understanding } \\
\hline & 1991 & 1992 & Differences \\
\hline Handicapped movement & 34.8 & 59.4 & +25.6 \\
\hline Farmers' movement & 40.1 & 59.1 & +19.0 \\
\hline Women's movement & 45.7 & 64.6 & +18.9 \\
\hline Non-homeowners' movement & 61.3 & 76.8 & +15.5 \\
\hline Labour movement & 52.2 & 66.2 & +14.0 \\
\hline Students' movement & 45.4 & 56.9 & +11.5 \\
\hline Environmental movement & 68.3 & 79.5 & +11.2 \\
\hline Aborigines' movement & 36.9 & 47.8 & +10.9 \\
\hline Judiciary reform movement & 42.9 & 53.2 & +10.3 \\
\hline Consumers' movement & 51.8 & 57.4 & +5.6 \\
\hline
\end{tabular}

Second, the handicapped movement gained the highest increase $(25.6 \%)$ of public understanding between 1991 and 1992, followed by the farmers' movement $(19 \%)$, the women's movement $(18.9 \%)$ and the non-homeowners' movement $(15.5 \%)$. The remaining five movements (labour, students', environmental, aborigines', and judiciary reform) all gained an increase above 10 per cent. Only the consumers' movement received less than a 10 per cent of increase in public understanding over the two-year period. It seems that the consumers' movement has made no headway at all in gaining more popular understanding.

Third, taking better public understanding, the rank order of the publicly understood movements also reveals that in both years, the environmental movement, the non-homeowners' movement and the labour movement scored higher than the other seven movements, 
while the consumers' movement dropped in rank from fourth in 1991 to seventh in 1992. Such rank order statistics highlight the sharply declining position of the consumers' movement in the eyes of the public between 1991 and 1992.

Fourth, if one further looks at the degree of public understanding and familiarity vis-à-vis each social movement, one finds that though seven of the ten movements were regarded by more respondents as unfamiliar in 1992 than in 1991, all ten movements have nevertheless gained an even better understanding from sectors of the concerned public. In short, the superficial familiarity or the so-called "public visibility" has not increased for most of the social movements. However, among the general public, there has been a steady increase of specific interested groups who have expressed a better understanding. The coexistence of the increases of public unfamiliarity and higher level of sophisticated understanding for social movements may seem ironic. The explanation may lie in the fact that Taiwan's social movements have not attracted the general public to learn about their causes, but they have indeed inspired the more concerned sectors of the public to gain a deeper understanding of them.

\section{Changes in the Public Support of Social Movements}

Table 4 sets out the percentages of support response; the rank order for each year; the difference between them; and the rank order according to the measure of change.

First, by looking at the rank order of support ratios for each year, it is found that the first six movements (environmental, consumers', handicapped, non-homeowners', judiciary reform and women's movement) not only received more than 50 per cent of public support, but their ranking also topped the others and there was no change in this respect over the two years. The students' movement, in both surveys, received the lowest support. By contrast, the environmental movement was supported by more than 80 per cent of the respondents, and the consumers' movement received more than 70 per cent support in both years.

Second, it is clear that public support for all social movements has increased over the two years. Among the ten movements, the farmers' movement gained the highest increase of support $(24.9 \%)$ between 1991 and 1992, followed by the women's movement $(13.5 \%)$, the non-homeowners' movement $(13.2 \%)$, and the judiciary 
reform movement (13.2\%). In both surveys, less than 30 per cent of the public gave their support to the students' movement, and there was almost no increase in public support at all over the two-year period.

Table 4: Rank order of public support of social movements, 1991-92

\begin{tabular}{|l|c|c|c|c|c|c|}
\hline Movement & $\begin{array}{c}1991 \\
(\%)\end{array}$ & $\begin{array}{c}\text { Rank } \\
\text { order }\end{array}$ & $\begin{array}{c}1992 \\
(\%)\end{array}$ & $\begin{array}{c}\text { Rank } \\
\text { order }\end{array}$ & $\begin{array}{c}1991-92 \\
\text { difference }\end{array}$ & $\begin{array}{c}\text { Rank } \\
\text { order }\end{array}$ \\
\hline Environmental movement & 82.4 & 1 & 87.7 & 1 & +05.3 & 6 \\
\hline Consumers' movement & 73.8 & 2 & 78.5 & 2 & +01.7 & 9 \\
\hline Handicapped movement & 66.2 & 3 & 71.9 & 3 & +05.7 & 5 \\
\hline Non-homeowners' movement & 58.4 & 4 & 71.6 & 4 & +13.2 & 3 \\
\hline Judiciary reform movement & 55.7 & 5 & 65.6 & 5 & +13.2 & 3 \\
\hline Women's movement & 51.9 & 6 & 65.4 & 6 & +13.5 & 2 \\
\hline Labour movement & 46.1 & 7 & 48.2 & 7 & +02.1 & 8 \\
\hline Aborigines' movement & 35.2 & 8 & 41.0 & 8 & +04.8 & 7 \\
\hline Farmers' movement & 29.5 & 9 & 54.4 & 9 & +24.9 & 1 \\
\hline Students' movement & 26.8 & 10 & 27.4 & 10 & +00.6 & 10 \\
\hline
\end{tabular}

\section{Social Attributes and Public Attitudes}

In the initial multiple regression analysis, six independent variables are used to determine their relative significance in marking the different attitudes towards social movements as a whole and towards each individual movement. Since income and class identification have a high correlation, subjective class identification is then adopted along with sex, age, education and ethnicity as the five social attribute variables. The dependent variables are the mean scores of public understanding and support for the social movements as a whole.

Table 5 is the result of the multiple regression analysis of the five independent background variables and the aggregate public understanding and support of the ten social movements as a whole.

First, judged by the results of a statistical significance test, the five background variables explained better the variations of overall understanding and support of the ten social movements in the 1991 survey than in the 1992 survey. Especially in the case of public understanding, the five variables in the 1992 survey have not been able to explain well the differences.

Second, among the five social attributes, education is the best discriminating background variable in differentiating the degree of 
overall understanding of social movements as a whole, followed by subjective class identification, sex and age.

Third, in the 1991 survey, after controlling other variables, male, younger, higher education, middle- to upper-middle-class respondents tended to have a greater understanding of and support for the emerging social movements. By contrast, female, older, lower educated, and lower-class respondents tended to view the social movements with less understanding and lower support.

On the other hand, in the 1992 survey, though the above general pattern holds true for support measures, it does not explain the differences in public understanding of the ten social movements as a whole.

Table 5: Regression analysis of public understanding and support of all social movements, 1991-92

\begin{tabular}{|c|c|c|c|c|c|c|c|c|}
\hline \multirow{3}{*}{$\begin{array}{l}\text { Independent } \\
\text { variable }\end{array}$} & \multicolumn{4}{|c|}{1991} & \multicolumn{4}{|c|}{1992} \\
\hline & \multicolumn{2}{|c|}{ Understanding } & \multicolumn{2}{|c|}{ Support } & \multicolumn{2}{|c|}{ Understanding } & \multicolumn{2}{|c|}{ Support } \\
\hline & B & B & B & B & B & B & B & B \\
\hline $\operatorname{Sex}(\mathrm{M})$ & 2.8465 & $0.1312^{3}$ & 1.4721 & $0.0749^{2}$ & 0.4744 & 0.0867 & 0.4229 & 0.0682 \\
\hline $30-39$ & 1.2465 & $0.0558^{1}$ & 0.2369 & 0.0117 & 0.7048 & $0.1247^{1}$ & -0.1315 & -0.0149 \\
\hline $40-49$ & -0.1212 & -0.0046 & -1.3930 & $-0.0585^{2}$ & 0.7316 & 0.1079 & -0.4392 & -0.0584 \\
\hline $50-64$ & -3.8893 & $-0.1354^{3}$ & 4.8394 & $-0.1861^{3}$ & 0.5290 & 0.0584 & -1.3545 & -0.1774 \\
\hline Middle school & 5.0425 & $0.1719^{3}$ & 4.8371 & $0.1822^{3}$ & 0.7007 & -0.0902 & 0.9076 & $0.1086^{\circ}$ \\
\hline High school & 9.7658 & $0.3964^{3}$ & 8.4270 & $0.3779^{3}$ & 0.4029 & 0.0710 & 1.5954 & 0.2294 \\
\hline Junior college & 13.2628 & $0.3625^{3}$ & 10.2542 & $0.3096^{3}$ & 1.0145 & $0.1543^{1}$ & 2.1948 & 0.2297 \\
\hline Above university & 13.1976 & $0.3523^{3}$ & 10.7165 & $0.3161^{3}$ & 1.8734 & $0.2749^{3}$ & 2.7300 & 0.2448 \\
\hline Taiwanese (Minnan) & -0.1212 & $-0.0704^{2}$ & -1.3827 & $-0.0577^{\prime}$ & 0.0902 & 0.0155 & -0.0680 & -0.0095 \\
\hline Taiwanese (Hakka) & -0.7475 & -0.0193 & 0.7776 & 0.0222 & 0.1006 & 0.0116 & 0.1113 & 0.0116 \\
\hline Upper class & 6.7573 & $0.0439^{1}$ & 1.3978 & 0.0100 & 0.0300 & 0.0012 & 1.6384 & 0.0489 \\
\hline Upper-middle class & 4.6553 & $0.1250^{3}$ & 3.9983 & $0.1186^{3}$ & -0.3167 & -0.0453 & 0.7215 & $0.0680^{2}$ \\
\hline Middle class & 2.5344 & $0.1169^{3}$ & 2.7390 & $0.1395^{3}$ & -3.840 & -0.0712 & 0.3676 & 0.0592 \\
\hline Lower class & -0.8988 & -0.0219 & -0.7201 & -0.0194 & -3.608 & $-0.1483^{2}$ & -0.3006 & -0.023 \\
\hline (Constant) & 9.2130 & & & & & & & \\
\hline $\mathrm{R}^{2}$ & 0.4 & & 0.4 & & 0.1 & $220^{3}$ & & $131^{3}$ \\
\hline
\end{tabular}

Key: B: regression coefficient $\quad B$ : standardized coefficient

$$
{ }^{1} \mathrm{P}<0.05 \quad{ }^{2} \mathrm{P}<0.01 \quad{ }^{3} \mathrm{P}<0.001
$$

Turning to the social attributes and public understanding and support of each individual social movement, the logistic regression analysis is applied. From the analysis, the following observations can be made. 
First, for both 1991 and 1992, the education variable is once again the most useful indicator in differentiating the respondents' understanding and support of each social movement. This is especially true for the differences in public understanding: that is, better educated people had a greater understanding. The gender variable is the second best indicator in explaining the different degrees of public understanding of each social movement: it indicates that the male respondents possessed a greater understanding than the female ones. Other social attributes have much less differentiating power in this respect. It seems clear that those with a higher education, of a younger age, and male tend to have a better understanding of every individual movement, though their support is not necessarily so clear.

Second, among the ten social movements, the following tendencies should also be pointed out for the 1991 survey:

- The environmental movement was less understood by the Minnan Taiwanese than by the Mainlanders.

- The aborigines' movement received greater support from the Hakka Taiwanese, another ethnic minority group in Taiwan.

- The women's movement received less support from the Minnan Taiwanese, than did the Mainlanders' movement.

- The non-homeowners' movement also received less support than the Mainlanders movement from the Minnan Taiwanese.

- Males tend to give significantly less support to the women's movement.

- People aged between 50 and 65 also tend to understand less and give less support to the non-homeowners' movement and labour movement, compared to the under-30 age group.

- For the 1992 survey, the following results came to light:

- The students' movement was less understood by the Minnan Taiwanese and less supported by the 40-49 age group and by high school graduate respondents.

- The farmers' movement gained much greater support among the Minnan and Hakka Taiwanese.

- The Minnan and Hakka Taiwanese also tended to give less support to the handicapped movement.

- Males had a poorer understanding of the women's movement than did the females.

- The Minnan Taiwanese expressed a lower understanding of the women's movement. 
- The older the respondents, the less support they rendered to the non-homeowners' movement.

- Males exhibited much greater understanding and support of the judiciary reform movement than did females.

- The middle class was quite reluctant to give support to the labour movement.

\section{Constructing a Typology of Social Movement Based on Public Understanding and Support}

The foregoing analysis of the self-reported public understanding and support of the ten emerging social movements in the early 1990s, reveals that these movements are perceived and received differently by various segments of the Taiwanese society. However, in both surveys, two emerging types of social movements are found (see table 6).

Table 6: Rank order of the difference between public understanding and support of social movements 1991-92

\begin{tabular}{|l|c|c|c|c|c|c|}
\hline Type A. Social movements where public support is higher than understanding \\
\hline & \multicolumn{3}{|c|}{1991} & \multicolumn{3}{|c|}{1992} \\
\hline & $\begin{array}{c}\text { Support/ } \\
\text { Under- } \\
\text { standing }\end{array}$ & $\begin{array}{c}\text { Differ- } \\
\text { ence }\end{array}$ & Rank & $\begin{array}{c}\text { Support/ } \\
\text { Under- } \\
\text { standing }\end{array}$ & $\begin{array}{c}\text { Differ- } \\
\text { ence }\end{array}$ & Rank \\
\hline Consumers' movement & $73.8 / 51.8$ & 22.0 & $\mathbf{1}$ & $78.5 / 57.4$ & 21.1 & 1 \\
\hline Handicapped movement & $66.2 / 34.8$ & 21.4 & 2 & $71.9 / 59.4$ & 12.5 & 2 \\
\hline Environmental movement & $82.4 / 68.3$ & 14.1 & 3 & $87.7 / 79.5$ & 8.2 & 4 \\
\hline Judiciary reform movement & $55.7 / 42.9$ & 12.8 & 4 & $65.6 / 53.2$ & 12.4 & 3 \\
\hline Women's movement & $51.9 / 45.7$ & 6.2 & 5 & $65.4 / 64.6$ & 0.8 & 5 \\
\hline
\end{tabular}

\begin{tabular}{|l|c|c|c|c|c|c|}
\hline & \multicolumn{3}{|c|}{1991} & \multicolumn{3}{c|}{1992} \\
\hline & $\begin{array}{c}\text { Under- } \\
\text { Type B. Social Movementing/ } \\
\text { support }\end{array}$ & Difference & Rank & $\begin{array}{c}\text { Under- } \\
\text { standing/ } \\
\text { support }\end{array}$ & Difference & Rank \\
\hline Students' movement & $45.4 / 26.8$ & 18.6 & 1 & $56.9 / 27.4$ & 28.5 & 1 \\
\hline Farmers' movement & $40.1 / 29.5$ & 10.6 & 2 & $59.1 / 54.4$ & 4.7 & 5 \\
\hline Labour movement & $52.2 / 46.1$ & 6.1 & 3 & $66.2 / 48.2$ & 18.0 & 2 \\
\hline $\begin{array}{l}\text { Non-homeowners' } \\
\text { movement }\end{array}$ & $61.3 / 58.4$ & 2.9 & 4 & $76.8 / 71.6$ & 5.2 & 4 \\
\hline Aborigines' movement & $36.9 / 35.2$ & 1.7 & 5 & $47.8 / 41.0$ & 6.8 & 3 \\
\hline
\end{tabular}

The Type A social movements are the ones where public support is greater than public understanding. These include the consumers', 
environmental, handicapped, women's and judiciary reform movements. The Type B social movements, on the other hand, consist of the aborigines', students', labour, farmers' and nonhomeowners' movements, where public understanding has been greater than public support. The difference between public understanding and support for each movement of the above two types also varies.

The following observations can be drawn from table 6. First, it is found that the Type A social movements are in general not only better supported by the public, they are also more readily understood by the public than Type $B$. It seems reasonable to assert that the public tend to support those movements that concern an overall reform of the society such as the environmental movement, the consumers' movement, the judiciary reform movement, and the women's movement, and they also support movements representing socially recognized disadvantageous groups such as the handicapped. Moreover, the demands and objectives of the Type A social movements are generally easily understood by the public and they have enjoyed higher visibility through the media over the years.

Second, except for the non-homeowners' movement, Type B social movements have been less supported and understood by the public than have Type A movements. The demands and objectives of these movements are narrower than the Type A movements, as they are organized by specific protest groups such as students, farmers, labourers and aborigines. They are also more controversial in their aims, easily raising anxiety and uneasiness among the public by their demands and protest activities. In other words, the Type B social movements can more easily be misunderstood by some sectors of the public, thereby engendering a non-supportive attitude in general.

Third, the case of the consumers' movement and the handicapped movement (both Type A) and the students' movement (Type B) are rather special. The consumers' and handicapped movements have enjoyed much greater support from the public, even from those who might not have really understood them. The public in Taiwan society clearly holds an especially favourable attitude towards movements with overall reform objectives that are less political in nature (e.g. the consumers' movement), or with objectives aimed to help the obviously disadvantageous groups (e.g. the handicapped 
movement). By contrast, the public tends to mistrust and disapprove of the students' movement, even when they claim to understand it. Obviously, the students' movement can be characterized as one of the most controversial social movements in present-day Taiwanese society. Such a sharp contrast between public understanding and support of the students' movement might well reflect the paternalistic ideology still dominating the adult population in Taiwan.

Lastly, the aborigines' movement is probably the most neglected social movement of all. The public apparently lacks a genuine concern for the ethnic minority.

In order to further illustrate how the social movements are subjectively constructed by the public, an emerging typology of all ten movements is developed in table 7.

Table 7: A typology of social movement by levels of public understanding and support

\begin{tabular}{|c|c|c|c|c|}
\hline & \multicolumn{2}{|c|}{ Support higher than understanding } & \multicolumn{2}{|c|}{ Support lower than understanding } \\
\hline & $\begin{array}{l}\text { High support level } \\
\text { (above } 50 \%)\end{array}$ & $\begin{array}{c}\text { Low support } \\
\text { level } \\
\text { (below } 50 \% \text { ) }\end{array}$ & $\begin{array}{c}\text { High support } \\
\text { level } \\
\text { (above } 50 \% \text { ) }\end{array}$ & $\begin{array}{l}\text { Low support level } \\
\text { (below 50\%) }\end{array}$ \\
\hline $\begin{array}{c}\text { High } \\
\text { under- } \\
\text { standing } \\
\text { level } \\
(\text { above } \\
50 \%)\end{array}$ & \begin{tabular}{|c|} 
Type I \\
Consumers' movement \\
$(1992.1991)$ \\
Environmental \\
movement \\
$(1992.1991)$ \\
Handicapped \\
movement (1992) \\
Women's movement \\
$(1992)$ \\
Judiciary reform \\
movement \\
$(1992)$
\end{tabular} & & $\begin{array}{c}\text { Type II } \\
\text { Non-home- } \\
\text { owners' } \\
\text { movement } \\
\text { (1992.1991) } \\
\text { Farmers' } \\
\text { movement } \\
(1992)\end{array}$ & $\begin{array}{c}\text { Type III } \\
\text { Labour movement } \\
(1992.1991) \\
\text { Students' movement } \\
(1992)\end{array}$ \\
\hline $\begin{array}{l}\text { Low under- } \\
\text { standing } \\
\text { level } \\
\text { (below } \\
50 \%)\end{array}$ & $\begin{array}{c}\text { Handicapped } \\
\text { movement (1991) } \\
\text { Women's movement } \\
(1991) \\
\text { Judiciary reform } \\
\text { movement (1991) }\end{array}$ & & & $\begin{array}{c}\text { Type IV } \\
\text { Students' movement } \\
\text { (1991) } \\
\text { Farmers' movement } \\
\text { (1991) } \\
\text { Aborigines' movement } \\
\text { (1992.1991) }\end{array}$ \\
\hline
\end{tabular}

The ten social movements are grouped according to either high or low understanding and support they have received from the public in each year. The dividing line between high and low classification is set at the 50 per cent mark. 
The following four new types of the ten social movements can then be constructed as they have been evaluated in the public mind in 1991 and 1992.

- Type I are those social movements with both high public understanding and high public support, but where the support is greater than understanding. Included in this type are the consumers' movement and environmental movements for both years. The handicapped, women's and judiciary reform movements also fall into this category for 1992, as they gained increased understanding between 1991 and 1992. The public support of the Type I movements is largely unreserved. It is safe to say that they probably are the most popular social movements in Taiwan.

- Type II includes social movements with both high public understanding and high public support, but where support is lower than understanding. For both years, the non-homeowners' movement has been of this type. The farmers' movement also belonged to this category in 1992, as it has apparently gained much higher public understanding and support between 1991 and 1992. Although the public has given enthusiastic support to these movements, their keen understanding is even greater.

- Type III consists of social movements with high public understanding and low support. The labour and students' movements both belonged to this group in 1992. Obviously, these two social movements are understood well by the public yet viewed with suspicion and mistrust; they have been unable to attract more support.

- Type IV can be called the lonely social movement in present-day Taiwan society as it receives both low understanding and low support. As pointed out earlier, the aborigines' movement has faced such a fate in both 1991 and 1992. In 1991, the students' movement and farmers' movement were in this category as well.

This typology of social movements also reveals the continuity or change in public attitudes. The public has apparently held consistently favourable attitudes towards the consumers' movement and environmental movement (Type I), while they have constantly treated the aborigines' movement rather negatively (Type IV). Nor have they changed their attitudes towards the non-homeowners' movement (Type II) and labour movement (Type III), though the pattern is different. However, the public attitude has varied towards 
the remaining five social movements. For the handicapped, women's, and judiciary reform movements, the public has increased their understanding yet their rather high support has been unchanged. The public also gained a better understanding of the students' movement, but their low support has remained static. Finally, the public has radically altered its attitude towards the farmers' movement with both higher understanding and support, though public support is still lower than public understanding.

\section{Conclusion}

Two comparative typologies of the emerging social movements in Taiwan are presented in this essay. The first typology is constructed in terms of the objective characteristics of different movements as manifested by their ability to mobilize internal resources and their immediate impact on the state (see table 1). The second typology, on the other hand, is constructed mainly from subjective perceptions of and attitudes towards different social movements (see table 7).

The two typologies of social movements are constructed by means of different theoretical thinking and empirical grounds, and they provide different ways of looking at Taiwan's emerging social movements from the 1980 s to the early 1990s. As already pointed out, the framework of classification of the typology in table 1 is derived from the resource mobilization model: the empirical observations on which the typology is based are the different objective performances of each social movement since its emergence. The analytical purpose of this typology is therefore to assess how successful different social movements have been in exerting pressure on the state so as to accomplish their stated objectives. Such a typology is useful in characterizing different social movements and in evaluating their respective trajectories of development in Taiwan's mobilized civil society.

However, the classification scheme of the typology in table 7 is mostly based on the constructionist perspective and with empirical investigation of how different social movements have actually been received by the public. Such a typology is also useful in characterizing different social movements by assessing their relative status in the civil society of Taiwan. 
One might assume that the public attitude towards different social movements derives from a perception of how these social movements have influenced the state. One could also hypothesize that with a more favourable attitude from the public, a social movement could enjoy greater legitimacy in the civil society and thus press the state for specific reforms more successfully. Those two theoretical observations certainly deserve further empirical verification. For the present, the two typologies presented here may provide some preliminary assessment of the above two assertions.

By comparing the different locations of each respective social movement as classified in both the objective typology in table 1 and the subjective typology in table 7 , one is tempted to conclude that the objective performance of a social movement in bringing about significant impact on the state might reflect its relative subjective position in the public's mind. In other words, the public's favourable or unfavourable attitude towards a specific social movement might determine its relative power relations vis-à-vis the state. However, this would be an erroneous assumption: the public and the state perceive social movements quite differently.

For example, even though the consumers' movement and environmental movement have been the two most popular movements in the public mind, they have not had a great immediate impact on the state in changing its pro-business and pro-growth ideology and policies. The same is true for the non-homeowners' movement. One the other hand, the labour movement has not enjoyed great support from the public, but it did exert sufficient immediate pressure on the state to elicit a response. The same is true for the students' movement and aborigines' movement.

A further analysis of the two typologies provides some insight into the possible course of development of Taiwan's different social movements. As the KMT state is being democratized and becoming more and more responsive to the demands of civil society, the role of public opinion is to augment its influence on the state's policies and behaviour: the social movements that have high public legitimacy might as well increase the public's political influence.

It is likely that the consumers', welfare, women's, and judiciary reform movements will increase their influence in the future policymaking process as these five social movements have been enjoying sufficient understanding and support from the public. To a lesser 
extent, the non-homeowners' and farmers' movements might reach a similar status as well. On the other hand, the labour, students', and aborigines' movements could face increasing difficulties in gaining higher legitimacy from the public in their effort to bring about further changes in state policies. In other words, how to redirect the subjective collective sentiments from the public will become an increasingly important task for the organizers of these social movements. In short, the legitimacy issue will be critical to them and therefore it will be crucial for them to mobilize public acceptance and support in the future.

Hsin-Huang Michael Hsiao is director of the Program for Southeast Asian Area Studies (PROSEA) at Academia Sinica in Taipei, as well as a research fellow at Academia Sinica's Institute of Sociology. He is also professor of sociology at National Taiwan University.

\section{NOTES}

1 Dieter Rucht, ed., Research on Social Movements: The State of the Art in Western Europe and the U.S.A. (Frankfurt am Main: Campus Verlag, 1991).

2 Hsin-Huang Michael Hsiao, "The Rise of Social Movements and Civil Protests", in Tun-jen Cheng and Stephan Haggard, eds., Political Change in Taiwan (Boulder \& London: Lynn Rienner Publishers, 1992), pp. 57-72. Hsin-Huang Michael Hsiao, "The Labour Movement in Taiwan: A Retrospective and Prospective Look", in Denis F. Simon and Michael Y. M. Kau, eds., Taiwan: Beyond the Economic Miracle (Armonk, NY: M.E. Sharpe,
1992), pp. 151-67. Hsin-Huang Michael Hsiao with Hwa-Jeng Liu, "Land-Housing Problems and the Limits of the Non-Homeowners' Movement in Taiwan", in Hong Kong Journal of Social Sciences, Vol. 2 (1993), pp. 1-20. H. H. Michael Hsiao, Lester Milbrath and Robert Weller "Antecedents of the Environmental Movement in Taiwan", in Capitalism, Nature, Socialism: A Journal of Socialist Ecology, Vol. 6, No. 3 (1995), pp. 91-104.

3 John Kean, ed., Civil Society and the State (London \& New York: Verso, 1988). 